\title{
Physical-mechanical properties of laminated bamboo panels ${ }^{1}$
}

\author{
Fernando Rusch ${ }^{2}$, Rômulo Trevisan ${ }^{3}$, Éverton Hillig², Erick Chagas Mustefaga²
}

\section{ABSTRACT}

Bamboo is a material used on a global scale in several areas. However, it needs adaptation in the processes for industrial use, in Brazil. The production of glued laminated panels has been growing in the world and this material can be a source of resources for this purpose. This study aimed to evaluate the physical-mechanical properties of laminated bamboo panels produced with two species (Phyllostachys aurea and Dendrocalamus asper) and two production processes/ adhesives (glued-laminated bamboo and thermo-mechanical laminated bamboo). For the mechanical properties analysis, specimens removed from the panels were subjected to shear tests, Janka hardness and static bending. The same specimens were used to determine the apparent density, moisture content and degree of compression. The apparent density varied between $0.75 \mathrm{~g} \mathrm{~cm}^{-3}$ and $0.79 \mathrm{~g} \mathrm{~cm}^{-3}$, with equilibrium moisture contents between $7.83 \%$ and $10.42 \%$. The highest values for the mechanical properties were verified in the thermo-mechanical laminated process. For $D$. asper, the modulus of rupture was 146.8 MPa, the shear glued line 6.36 MPa and the Janka hardness $3,852 \mathrm{~N}$, while, for $P$. aurea, the modulus of elasticity reached $19,603 \mathrm{MPa}$. It was concluded that the production of bamboo laminated panels, especially using the thermo-mechanical process, can be a potential alternative.

KEYWORDS: Glued-laminated bamboo, thermo-mechanical laminated bamboo, polyvinyl acetate, phenol-formaldehyde.

\section{INTRODUCTION}

Bamboo, as it is commonly called, consists of libero-woody bundles, that is, an approximately circular structure that encompasses vascular tissues of primary phloem (liber) and primary xylem (ligneous). The term ligneous, in fact, would not be the most indicated, because the wood only originates from the

\section{RESUMO}

\section{Propriedades físico-mecânicas}

de painéis de bambu laminado

O bambu é um material utilizado em escala global em diversas áreas. Contudo, necessita de aprimoramento nos processos para utilização industrial, no Brasil. A produção de painéis laminados colados está em crescimento no mundo e pode ser uma fonte de recursos para esse fim. Objetivou-se avaliar as propriedades físico-mecânicas de painéis laminados de bambu produzidos com duas espécies (Phyllostachys aurea e Dendrocalamus asper) e dois processos produtivos/adesivos (laminado colado e termomecânico). Para as análises mecânicas, corpos de prova retirados dos painéis foram submetidos a ensaios de cisalhamento, dureza Janka e flexão estática. Os mesmos corpos foram utilizados para a determinação da massa específica aparente, teor de umidade e grau de compressão. A massa específica aparente variou entre $0,75 \mathrm{~g} \mathrm{~cm}^{-3}$ e $0,79 \mathrm{~g} \mathrm{~cm}^{-3}$, com teor de umidade de equilíbrio entre 7,83\% e 10,42\%. Os maiores valores das propriedades mecânicas foram verificados no bambu laminado termomecânico. Para D. asper, o módulo de ruptura foi de $146,8 \mathrm{MPa}$, a resistência ao cisalhamento na linha de cola de $6,36 \mathrm{MPa}$ e a dureza Janka atingiu 3.852 N, enquanto, para $P$. aurea, constatou-se 19.603 MPa no valor do módulo de elasticidade. Concluiu-se que a produção de painéis laminados de bambu, em especial no processo termomecânico, é uma potencial alternativa.

PALAVRAS-CHAVE: Bambu laminado colado, bambu laminado termomecânico, poliacetato de vinila, fenol-formaldeído.

secondary xylem; however, it is already of common use for the monocotyledons.

Classified as a representative of the Gramineae or Poaceae family, Bambusoideae subfamily, it is estimated the existence of 119 genera, with 1,482 species in the world (Clark et al. 2015). In Brazil, there are 258 species, of which 175 are endemic and the others were introduced (Filgueiras \&

1. Received: Jun. 28, 2018. Accepted: Oct. 15, 2018. Published: Feb. 08, 2019. DOI: 10.1590/1983-40632019v4953714.

2. Universidade Estadual do Centro-Oeste, Departamento de Engenharia Florestal, Irati, PR, Brasil.

E-mail/ORCID: fe_rusch@yahoo.com.br/0000-0001-5221-835X, hillig@hotmail.com/0000-0002-7895-2453, erick_mustefaga@hotmail.com/0000-0001-8298-7897.

3. Universidade Federal de Santa Maria, Departamento de Engenharia Florestal, Frederico Westphalen, RS, Brasil.

E-mail/ORCID: romulo_trevisan@yahoo.com.br/0000-0002-8535-0119. 
Viana 2017). It was estimated that, in 2010, there were $31,470,000$ ha of bamboo in the world and 9,300,000 ha in Brazil, the country with the largest area of total coverage of this plant (FAO 2010).

However, despite having extensive areas of bamboo, Brazil still does not present a satisfactory use of this raw material. This fact can be seen in comparison with China, which, with a smaller area, enables hundreds of panel plants, especially floors, allowing that, from 1996 to 2017, the export of bamboo products reached a monthly average of 12,595.14 USD THO (Trading Economics 2018), exported to several countries in Europe, USA and Japan, and even to Brazil. Another important aspect reported by the Chinese Forestry Administration, from 2013, is that the total value of bamboo forests production should reach US\$ 48 billion by the end of 2020 (Phimmachanh et al. 2015). Besides the representative billing, China has the technological domain of the bamboo-based process of panels and floors industrialization (Berndsen et al. 2013).

The diversity of species and areas of bamboo, both in Brazil and in the world, can be an alternative to supply the market of wood products, in a scenario increasingly directed to the reduction of deforestation and the development of technologies that enable sustainable products (Paes et al. 2009). In addition, bamboo has an appearance and workability similar to the wood of traditional tree species, being valued in the European and American markets, and can be used not only in its natural form, but also for the manufacture of veneers. For Rosa et al. (2014 and 2016), the panel type with the most widespread production technology is the so-called glued-laminated bamboo (GLB), which began in China in the 1980s (Berndsen et al. 2013). The high temperature pressing was incorporated sequentially.

The Dendrocalamus asper (Schult. \& Schult.f.) Baker ex. K. Heyne species, which reaches up to $30 \mathrm{~m}$ in height and $20 \mathrm{~cm}$ in diameter, grows in clumps and reaches a high productivity (Mognon et al. 2015). Another species that stands out in the national scenario is Phyllostachys aurea (Carrière) Rivière et $\mathrm{C}$. Rivière. It reaches $8 \mathrm{~cm}$ in diameter and $10 \mathrm{~m}$ in height and propagates in a sprawling system. In Brazil, the $D$. asper species is mainly used in handmade processes for the manufacture of cold-rolled laminated panels, while $P$. aurea is used especially in bare handcrafted furniture.
The following values were respectively found for the mechanical properties of tensile, compression, bending (modulus of rupture and elasticity) and shear strength of D. asper: $285.0 \mathrm{MPa}, 50.5 \mathrm{MPa}$, 89.0 MPa, 24,050.0 MPa and 6.6 MPa (Pereira 2012, Carbonari et al. 2017). For P. aurea, the average values of samples of the base, middle and top (with and without node), air dried, presented tensile, compression and shear properties of $210.0 \mathrm{MPa}$, 69.0 MPa and 4.0 MPa, respectively (Cruz 2002).

A limiting aspect for the production of GLB in the national scenario is the lack of suitable equipment to carry out its rolling (Beraldo \& Rivero 2003), what may interfere with the material surface quality. Another important factor is the difficulty in bonding the bamboo, influenced by the adhesive type and pressure used (Carrasco et al. 2017). However, an alternative that seems to reverse these limitations is the adoption of the thermomechanical process used for wood, due to the reduction of the empty spaces volume in the material, by means of compression, promoting a density increase.

In thermally treated woods, Moura et al. (2012) verified that there is a higher temperature effect in the modulus of rupture, if compared to the elasticity. On the other hand, in the production of plywood panels, the pressing parameters should be controlled, and adhesives that are appropriate to the characteristics of the veneers and the final panel use should be applied (Iwakiri et al. 2012, Trianoski et al. 2015).

In this context, the hypothesis formulated was that bamboo can be used in the national scenario as an alternative for the laminated panels production, provided the suitable species and the methodological processes are determined. Thus, this study aimed to evaluate the physical-mechanical properties of bamboo panels produced with two bamboo species and two productive/adhesive processes.

\section{MATERIAL AND METHODS}

The study was carried out at the Universidade Estadual do Centro-Oeste (Unicentro), in Irati, Paraná state, Brazil, between March and June 2018. Mature bamboo stems (older than 4 years old) of two species were used: Phyllostachys aurea, from Unicentro; and Dendrocalamus asper, from Planalto, Rio Grande do Sul state, Brazil.

Two types of adhesive were used: polyvinyl acetate (PVA), in its commercial form, and a glue 
beat composed of phenol-formaldehyde (PF), with $35 \%$ of solids content, in a mixture of adhesive $(69 \%)$, wheat flour $(13 \%)$ and water $(18 \%)$. The physical and chemical parameters of these adhesives are shown in Table 1.

For the production of $D$. asper splits, bamboo stems were harvested with a chainsaw and cut (1.4 m length) with a top circular saw (Figure 1A). The lateral squaring was performed on a double sawing saw (Figure 1B) and, with a circular saw (Figure 1C), the internal nodes were removed. After these procedures, the rough splits were flattened to uniform the faces and the inner and outer wall layers were eliminated, in order to improve the assembly and bonding process (organization of parts and adhesive distribution).

For the production of $P$. aurea splits, the nodes were removed from the bamboo stems (Figure 2A), being hydraulically pressed (Figures $2 \mathrm{~B}$ and $2 \mathrm{C}$ ) under $25 \mathrm{kgf} \mathrm{cm}^{-2}$ and $120^{\circ} \mathrm{C}$, generating splits of its entire wall (Figure 2D). Then, by sanding, its inner layer was removed, while the outer layer (bark) was not removed, because it was not glued at any time, and was always on the panel edges.

In the panel production, the processes called glued-laminated bamboo (GLB) and thermomechanical laminated bamboo (TMLB) were used.

Table 1. Physical and chemical characterization of the adhesives used.

\begin{tabular}{lcc}
\hline \multirow{2}{*}{$\begin{array}{c}\text { Physical and } \\
\text { chemical properties }\end{array}$} & $\begin{array}{c}\text { Polyvinyl } \\
\text { acetate }\end{array}$ & Phenol-formaldehyde \\
\hline Solids content $(\%)$ & $51-53$ & $48-51$ \\
Viscosity - cP $\left(25^{\circ} \mathrm{C}\right)$ & $6,000-8,000$ & $400-800$ \\
$\mathrm{pH}$ & $4.0-5.0$ & $11.5-13.0$ \\
$\mathrm{Gel}$ time & $>3 \mathrm{~h}$ & $6-11 \mathrm{~min}$ \\
Density - $\mathrm{g} \mathrm{cm}^{-3}\left(25^{\circ} \mathrm{C}\right)$ & 1.05 & $1.19-1.25$ \\
\hline
\end{tabular}

Source: Abimci (2009); Henkel (2012).

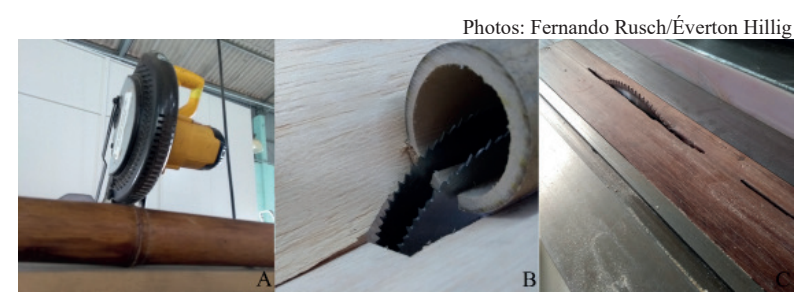

Figure 1. Equipment used for cutting and producing Dendrocalamus asper splits. A) top circular saw; B) double sawing saw; C) circular saw.
The adhesives were applied between the two layers (with a $50 \%$ overlap) and on their side faces, except for the edge faces (Figure 3).

For GLB, the pressing took place with a manual press, using F-clamps, at ambient temperature, for $6 \mathrm{~h}$; while the TMLB was placed in a hydraulic press, with a temperature of $120^{\circ} \mathrm{C}$ and pressure of $25 \mathrm{kgf} \mathrm{cm}^{-2}$, for $10 \mathrm{~min}$. In order to avoid exaggerated and uneven compaction during pressing, metal retaining bars of $15 \mathrm{~mm}$ thickness were used in the hydraulic press template, in order to obtain standardized parts. For both species and processes/adhesives, panels of $350 \mathrm{~mm} \times 105 \mathrm{~mm}$ (length $\mathrm{x}$ width) were produced; however, a variation in thickness occurred.

After the panel production, specimens were cut for the mechanical tests of static bending (modulus of rupture and modulus of elasticity), shear strength and Janka hardness, being the latter with two impressions per specimen. Six replicates were performed for each property and panel type evaluated, following the European standard designations (ECS 1993) for the modulus of rupture and modulus of elasticity determination and the American Society for Testing and Materials (ASTM 2006) ones for shear strength and Janka hardness. Also, commercial bamboo floor

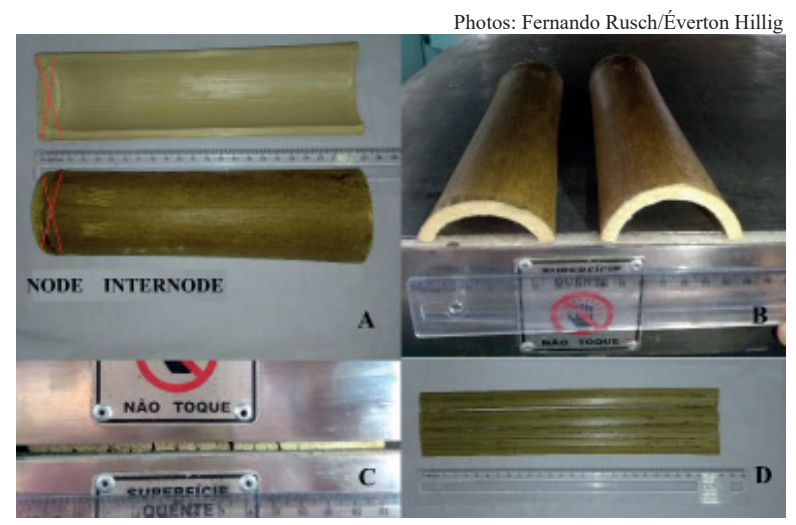

Figure 2. Production process of Phyllostachys aurea splits. A) Used bamboo portion (internode); B and C) mechanical pressing; D) produced splits (after pressing).

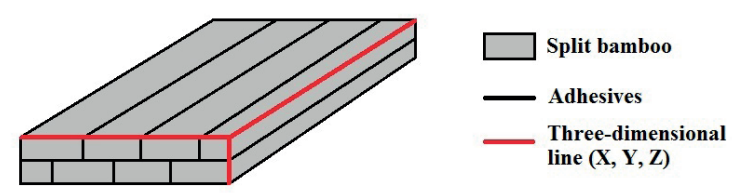

Figure 3. Splits organization for the panels glued process. 
specimens of Phyllostachys pubescens of Asian origin were tested.

The density and equilibrium moisture content of the specimens at the test time were determined following the Brazilian regulatory standard (ABNT 1997). For the static bending test, the maximum load was reached between $30 \mathrm{~s}$ and $90 \mathrm{~s}$, and was performed in a 3-point apparatus, using the span 17 times the specimen thickness with width of $50 \mathrm{~mm}$. For the shear test, specimens of $51 \mathrm{~mm} \times 50 \mathrm{~mm}$, with an overlapped area of $1,600 \mathrm{~mm}^{2}$, were tested at a speed of $0.6 \mathrm{~mm} \mathrm{~min}^{-1}$. The hardness test used specimens of $150 \mathrm{~mm} \times 50 \mathrm{~mm}$ and a ball with $11.3 \mathrm{~mm}$ of diameter and speed of $1.3 \mathrm{~mm} \mathrm{~min}^{-1}$. The thickness was measured with a digital caliper $(0.01 \mathrm{~mm})$, before and after the panel production. To determine the thickness variation, the relation between the final and initial thickness was used, as described in the following equation:

$$
\mathrm{Tv}=\frac{\mathrm{Ti}-\mathrm{Tf}}{\mathrm{Tf}} \times 100
$$

where, $T v$ is the thickness variation (\%); Ti the initial thickness (mm); and $T f$ the final thickness ( $\mathrm{mm}$ ).

The experimental design (Table 2) consisted of a $2 \times 2$ factorial arrangement, that is, panels produced with both species (D. asper and $P$. aurea) and with two bonding processes (with and without high temperature and pressure, besides adhesives suitable to the process).

Since the prerogatives for homogeneity of variance and normal distribution were satisfied, the statistical analysis of the panel physical and mechanical properties was performed by analysis of variance (Anova; $\mathrm{p}<0.05$ ), under a factorial design, considering the species and process/adhesive principal effects and their interaction. The Tukey test was used $(\mathrm{p}<0.05)$.

\section{RESULTS AND DISCUSSION}

The mean values of the panel physical and mechanical properties of Phyllostachys aurea and Dendrocalamus asper (Table 3) showed that they presented a small variation in density. In general, there was an average thickness variation of $5.48 \%$ in the TMLB process, which did not provide an increase in the density higher than that verified in the GLB. This is probably due to the higher weight and solids content of the PVA adhesive used in the GLB process, which consequently increased the panel density. In relation to the equilibrium moisture

Table 2. Factors and variables of bamboo panels of Phyllostachys aurea and Dendrocalamus asper.

\begin{tabular}{cccccccc}
\hline \multirow{2}{*}{ Panel } & \multicolumn{3}{c}{ Factors } & \multicolumn{5}{c}{ Process parameters } \\
\cline { 2 - 8 } & Species & Processes & Adhesives & Grammage $\left(\mathrm{g} \mathrm{m}^{-2}\right)$ & Pressure $\left(\mathrm{kgf} \mathrm{cm}^{-2}\right)$ & Temperature $\left({ }^{\circ} \mathrm{C}\right)$ & Pressing $(\mathrm{min})$ \\
\hline \multirow{2}{*}{1} & P. aurea & GLB & PVA & 250 & 0.5 & $20-30$ & 720 \\
2 & P. aurea & TMLB & PF & 180 & 25.0 & 120 & 10 \\
3 & D. asper & GLB & PVA & 250 & 0.5 & $20-30$ & 720 \\
4 & D. asper & TMLB & PF & 180 & 25.0 & 120 & 10 \\
\hline
\end{tabular}

GLB: glued-laminated bamboo; TMLB: thermo-mechanical laminated bamboo; PVA: polyvinyl acetate; PF: phenol-formaldehyde.

Table 3. Mean values of the physical and mechanical properties for parameters evaluated in the production of panels of Phyllostachys aurea and Dendrocalamus asper.

\begin{tabular}{|c|c|c|c|c|c|c|c|}
\hline \multirow{2}{*}{\multicolumn{2}{|c|}{ Parameters }} & \multicolumn{6}{|c|}{ Physical-mechanical properties } \\
\hline & & Density $\left(\mathrm{g} \mathrm{cm}^{-3}\right)$ & EMC (\%) & MOR (MPa) & $\operatorname{MOE}(\mathrm{MPa})$ & $\mathrm{ST}(\mathrm{MPa})$ & $\mathrm{JH}(\mathrm{N})$ \\
\hline \multirow{3}{*}{ Species } & P. aurea & 0.77 & 9.47 & 99.400 & $12,746.000$ & 0.810 & $1,647.000$ \\
\hline & D. asper & 0.77 & 8.69 & 135.200 & $13,059.000$ & 4.120 & $3,812.000$ \\
\hline & $\mathrm{F}$ test & $0.013^{\mathrm{ns}}$ & $14.948 *$ & $24.785 *$ & $0.109^{\mathrm{ns}}$ & $244.752 *$ & $360.420 *$ \\
\hline \multirow{3}{*}{ Process } & GLB & 0.78 & 9.04 & 104.500 & $8,552.000$ & 1.060 & $2,684.000$ \\
\hline & TMLB & 0.76 & 9.12 & 130.100 & $17,254.000$ & 3.870 & $2,774.000$ \\
\hline & F test & $13.714^{*}$ & $0.164^{\mathrm{ns}}$ & $12.646^{*}$ & $83.792 *$ & $176.341 *$ & $0.628^{\mathrm{ns}}$ \\
\hline Interaction & F test & $6.708^{*}$ & $78.004 *$ & $0.105^{\mathrm{ns}}$ & $27.808^{*}$ & $60.224^{*}$ & $0.006^{\mathrm{ns}}$ \\
\hline
\end{tabular}

EMC: equilibrium moisture content; MOR: modulus of rupture in static bending; MOE: modulus of elasticity in static bending; ST: shear strength; JH: Janka hardness; ${ }^{\text {ns }}$ not significant; * significant at $5 \%$. 
content, the mean value did not differ in the processes and specifically among the species. Lower values occurred for D. asper.

For modulus of rupture, in the different species and processes, significant differences were verified, mainly among the species. For modulus of elasticity, the values were equivalent among the species; however, the GLB process presented a value $50 \%$ lower than the TMLB. The shear strength for $P$. aurea and for the GLB process was lower, in relation to $D$. asper and TMLB. The hardness of the panels was independent of the processes used, and $D$. asper, traditionally used in the panel production, presented a mean value twice as high as $P$. aurea.

Density is a variable that influences the mechanical properties. Values of 95-126 MPa for modulus of rupture and $8,115-10,635 \mathrm{MPa}$ for modulus of elasticity were found by Ni et al. (2016), due to the variation of $0.6-0.9 \mathrm{~g} \mathrm{~cm}^{-3}$ in the density of GLB panels. In GLB panels, the modulus of rupture, modulus of elasticity and shear strength were dependent on the distribution and uniformity of the density (Chen et al. 2014). In the panels of this study, no variation of density was observed among the species; however, $D$. asper presented higher values for all the mechanical properties. For the effect of the production process, GLB presented a higher density value, but its mechanical properties were lower, certainly due to the pressing process used.

The values for density, modulus of elasticity and hardness of the panels produced with $P$. aurea and D. asper and the GLB and TMLB processes (Table 3) were in the range of those for Hymenolobium petraeum and Bagassa guianensis wood. H. petraeum had a density of $710 \mathrm{~kg} \mathrm{~m}^{-3}$ (12\% of moisture content), modulus of elasticity of $109.3 \mathrm{MPa}$ and perpendicular hardness of 5,589 N. B. guianensis ( $15 \%$ of moisture content) had a density of $820 \mathrm{~kg} \mathrm{~m}^{-3}$, modulus of rupture of $138.2 \mathrm{MPa}$, modulus of elasticity of $15,857 \mathrm{MPa}$ and parallel hardness of 7,207 N, being indicated for floor production (Nahuz 2013).

The thickness variation was $1.54 \%$ for P. aurea and $3.94 \%$ for D. asper, being $5.48 \%$ in the thermomechanical process. Also, when comparing the panels produced from this study with commercial plywood of species produced by Iwakiri et al. (2006) and Kazmierczak et al. (2017), it was found that the values for modulus of rupture, modulus of elasticity, shear strength and hardness of the bamboo panels were higher.

For D. strictus cold-pressed panels glued with epoxy resin, Verma et al. (2014) obtained a higher strength to softwood and similar to hardwoods, and verified that it can be used as an alternative to wood composites and to wood used for structural purposes.

There was no significant interaction between the factors analyzed for modulus of rupture and hardness; but, for the other properties, the interaction was verified (Table 3 ). Table 4 shows the values of the commercial panel properties and the different types of experimental panels, in order to analyze the interaction of the properties evaluated and visualize the means of all panel properties, including modulus of rupture and hardness, which did not present a significant interaction. In this analysis, the panel properties were evaluated considering the two processes in each species.

The lowest value for density occurred in the TMLB panels produced with $P$. aurea, being the panels that differed statistically from the one that presented the highest value (in this case, the GLB panels of $P$. aurea). The density and equilibrium moisture content of the experimental panels differed from the commercial one, which presented lower values. All panels had an equilibrium moisture content below $11 \%$, in accordance with the technical

Table 4. Physical-mechanical properties of panels produced with Phyllostachys aurea and Dendrocalamus asper and the commercial panel.

\begin{tabular}{cllcccccc}
\hline \multirow{2}{*}{$\begin{array}{c}\text { Panel } \\
\text { type }\end{array}$} & \multicolumn{2}{c}{ Evaluated effects } & \multicolumn{5}{c}{ Physical-mechanical properties } \\
\cline { 2 - 8 }$y$ & Species & Process & Density $\left(\mathrm{g} \mathrm{cm}^{-3}\right)$ & EMC $(\%)$ & MOR (MPa) & MOE (MPa) & ST (MPa) & JH (N) \\
\hline 1 & P. aurea & GLB & $0.79 \mathrm{a}^{*}$ & $8.54 \mathrm{~b}$ & $85.4 \mathrm{c}$ & $5,888 \mathrm{~d}$ & $0.22 \mathrm{c}$ & $1,597 \mathrm{c}$ \\
2 & P. aurea & TMLB & $0.75 \mathrm{~b}$ & $10.42 \mathrm{a}$ & $113.3 \mathrm{bc}$ & $19,603 \mathrm{a}$ & $1.39 \mathrm{~b}$ & $1,696 \mathrm{c}$ \\
3 & D. asper & GLB & $0.77 \mathrm{ab}$ & $9.55 \mathrm{a}$ & $123.6 \mathrm{ab}$ & $11,215 \mathrm{bc}$ & $1.89 \mathrm{~b}$ & $3,771 \mathrm{a}$ \\
4 & D. asper & TMLB & $0.77 \mathrm{ab}$ & $7.83 \mathrm{~b}$ & $146.8 \mathrm{a}$ & $14,904 \mathrm{~b}$ & $6.36 \mathrm{a}$ & $3,852 \mathrm{a}$ \\
5 & Commercial $^{1}$ & $0.64 \mathrm{c}$ & $6.64 \mathrm{c}$ & $115.4 \mathrm{~b}$ & $9,228 \mathrm{~cd}$ & $1.07 \mathrm{bc}$ & $2,951 \mathrm{~b}$ \\
\hline
\end{tabular}

EMC: equilibrium moisture content; MOR: modulus of rupture in static bending; MOE: modulus of elasticity in static bending; ST: shear strength; JH: Janka hardness. ${ }^{1}$ Commercial bamboo floor; * means followed by the same letter in the column do not differ by the Tukey test $(\mathrm{p}>0.05)$. 
parameters of Abimci (2009), for plywood panels. The thermomechanical process applied in TMLB provided a thickness variation of $3.08 \%$ for $P$. aurea and $7.88 \%$ for $D$. asper.

The $P$. aurea panels presented a lower modulus of rupture, shear strength and hardness than those of $D$. asper, for both processes using the PVA and $\mathrm{PF}$ adhesives. This is due to the fact that they were produced with the splitting of the entire twig wall (without node), and thus their side glue was hampered by the angle of the hydraulically compressed bamboo split, which presented cracks with irregular edges. This occurs because its cylindrical structure does not withstand the tension applied during the pressing process. Something similar would certainly occur if this split form process be applied to $D$. asper.

In addition, lower values in the $P$. aurea panels are attributed to the higher density of the stems, a condition that results in poor adhesives anchorage in the material. Higher values of the mechanical properties occurred in the TMLB panels. Apparently, the increase in pressure and temperature tends to plasticize the fibers, thus improving and standardizing the mechanical properties.

When comparing the values of the panel properties produced with $P$. aurea and those of commercial bamboo, the hardness was lower in both processes, despite having a higher density. For the other properties, there was a tendency, although not confirmed statistically, that the experimental panels of $P$. aurea presented inferior values for modulus of rupture and hardness in both processes and for modulus of elasticity and shear strength in the GLB process. For D. asper, also a statistically unconfirmed trend of modulus of rupture, modulus of elasticity and shear strength properties values was higher in the GLB process than in the commercial panel. The other properties (density, equilibrium moisture content and hardness) were statistically higher. In the TMLB process, the panels produced with $D$. asper presented values higher than the commercial panel for all the properties.

When comparing the GLB and TMLB panels produced in this study with the laminated bamboo panels of the same density, it is verified that the values found for modulus of rupture and modulus of elasticity were the highest ones. This is evidenced by the study of Ma et al. (2018), who used the process described by Deng et al. (2014) and Chen et al. (2016) to produce bamboo panels of Phyllostachys pubescens, having found $0.75 \mathrm{~g} \mathrm{~cm}^{-3}$ for density, 93.73 $\mathrm{MPa}$ for modulus of rupture and 9,720 MPa for modulus of elasticity, whereas Kravchenko et al. (2015), who analyzed the properties of GLB panels, found mean values of $0.605 \mathrm{~g} \mathrm{~cm}^{-3}$ for density (10\% of moisture content), 78.9 MPa for modulus of rupture and 9,638 MPa for modulus of elasticity.

The highest values for hardness of the panels produced in this study occurred for $D$. asper, respectively for GLB and TMLB, which were $27.8 \%$ and $30.5 \%$ higher than the commercial specimens analyzed. However, for GLB panels produced with PVA and resorcinol formaldehyde adhesives by Kravchenko et al. (2015), the average value of 4,570 N was found.

Due to the values observed in the physical and mechanical properties tests of this study, the proposed methodology was considered satisfactory. Therefore, it is possible to emphasize the potential of using bamboo to obtain laminated panels, especially when the process uses a high pressure and temperature during pressing, contributing to plasticize the fibers, standardize the density, improve and standardize the mechanical properties. In addition, this study may contribute to the development of specific standards for laminated bamboo panels, facilitating the characterization of physical and mechanical properties and the comparison with other studies.

\section{CONCLUSION}

The observed results for density, equilibrium moisture content, static bending, shear strength and hardness allow to state that bamboo panels have satisfactory properties, and those produced with Dendrocalamus asper fit into situations in which the average at high mechanical strength is required, in addition to high hardness.

\section{ACKNOWLEDGMENTS}

The authors would like to thank the Coordenação de Aperfeiçoamento de Pessoal de Nível Superior - Brasil (Capes; finance code 001), for partially financing this study.

\section{REFERENCES}

AMERICAN SOCIETY FOR TESTING AND MATERIALS (ASTM). Standard test methods for 
evaluating properties of wood-base fiber and particle panel materials: ASTM D 1037-06. West Conshohocken: ASTM, 2006.

ASSOCIAÇÃO BRASILEIRA DA INDÚSTRIA DA MADEIRA PROCESSADA MECANICAMENTE (Abimci). Compensado de pinus. Curitiba: Abimci, 2009.

ASSOCIAÇÃO BRASILEIRADE NORMAS TÉCNICAS (ABNT). Projeto de estruturas de madeira: NBR 7190. Rio de Janeiro: ABNT, 1997.

BERALDO, A. L.; RIVERO, L. A. Bambu laminado colado. Floresta e Ambiente, v. 10, n. 2, p. 36-46, 2003.

BERNDSEN, R. S. et al. Resistência à flexão estática e à compressão paralela do bambu-Mossô (Phyllostachys pubescens). Floresta, v. 43, n. 3, p. 485-494, 2013.

CARBONARI, G. et al. Bambu: o aço vegetal. Mix Sustentável, v. 3, n. 1, p. 17-25, 2017.

CARRASCO, E. V. M. et al. Resistência ao cisalhamento da ligação bambu-bambu: influência da pressão de colagem. Matéria, v. 22, e11914, 2017.

CHEN, F. M. et al. Evaluation of the uniformity of density and mechanical properties of bamboo-bundle laminated veneer lumber (BLVL). BioResources, v. 9, n. 1, p. 554$565,2014$.

CHEN, F. M. et al. The bending properties of bamboo bundle laminated veneer lumber (BLVL) double beams. Construction and Building Materials, v. 119, n. 1, p. 145151, 2016.

CLARK, L. G. et al. Bamboo taxonomy and habitat. In: LIESE, W.; KÖHL, M. (Eds.). Tropical forestry, bamboo: the plant and its uses. Hamburg: Springer, 2015. p. 1-30.

CRUZ, M. L. Caracterização fisicica e mecânica de colmos inteiros do bambu da espécie Phyllostachys aurea: comportamento à flambagem. 2002. 114 f. Dissertação (Mestrado em Engenharia Civil) - Pontifícia Universidade Católica do Rio de Janeiro, Rio de Janeiro, 2002.

DENG, J. C. et al. The effect of PF/PVAC weight ratio and ambient temperature on moisture absorption performance of bamboo-bundle laminated veneer lumber. Polymer Composites, v. 37, n. 3, p. 955-962, 2014.

EUROPEAN COMMITTEE FOR STANDARDIZATION (ECS). EN 310: plywood: determination of bending strength. Brussels: ECS, 1993.

FILGUEIRAS, T. S.; VIANA, P. L. Bambus brasileiros: morfologia, taxonomia, distribuição e conservação. In: DRUMOND, P. M.; WIEDMAN, G. (Eds.). Bambus no Brasil: da biologia à tecnologia. Rio de Janeiro: ICH, 2017. p. 10-27.
FOOD AND AGRICULTURE ORGANIZATION OF THE UNITED NATIONS (FAO). Global forest resources assessment. 2010. Available at: < http://www.fao.org/3/ai1757e.pdf $>$. Access on: 15 Oct. 2018.

HENKEL LTDA. Ficha de informação de segurança de produtos químicos: cascola cascorez extra - $\mathrm{n}^{\circ} 30-08-40$. Itapevi: Henkel Ltda., 2012.

IWAKIRI, S. et al. Produção de painéis compensados com lâminas de madeira de Sequoia sempervirens e resina ureia-formaldeído. Floresta, v. 42, n. 4, p. 809-816, 2012.

IWAKIRI, S. et al. Utilização de lâminas de Eucalyptus grandis e Eucalyptus maculata como alternativas para produção de piso laminado com montagem direta. Floresta, v. 36, n. 3, p. 425-430, 2006.

KAZMIERCZAK, S. et al. Painéis compensados fabricados com lâminas de três espécies de eucaliptos. Floresta e Ambiente, v. 24, e00111614, 2017.

KRAVCHENKO, G. A. et al. Eficiência de diferentes adesivos para a confecção de painéis de bambu laminado. Revista Eletrônica em Gestão, Educação e Tecnologia Ambiental, v. 19, n. 1, p. 212-219, 2015.

$\mathrm{MA}, \mathrm{X}$. et al. Long creep-recovery behavior of bamboobased products. Journal of Wood Science, v. 64, n. 2, p. 119-125, 2018.

MOGNON, F. et al. Locação e modelagem da biomassa em Dendrocalamus asper. Floresta, v. 45, n. 1, p. 1-10, 2015.

MOURA, L. F. et al. Efeitos da termorretificação na perda de massa e propriedades mecânicas de Eucalyptus grandis e Pinus caribaea var. hondurensis. Floresta, v. 42, n. 2, p. 305-314, 2012.

NAHUZ, A. R. Catálogo de madeiras brasileiras para a construção civil. São Paulo: IPT, 2013.

NI, L. et al. Manufacture and mechanical properties of glued bamboo laminates. BioResources, v. 11, n. 2, p. 4459-4471, 2016.

PAES, J. B. et al. Caracterização físico-mecânica do laminado colado de bambu (Dendrocalamus giganteus). Ciência Florestal, v. 19, n. 1, p. 41-51, 2009.

PEREIRA, M. A. dos R. Projeto bambu: introdução de espécies, manejo, caracterização e aplicações. 2012. 210 f. Tese (Livre Docência) - Universidade de São Paulo, Bauru, 2012.

PHIMMACHANH, S. et al. Bamboo resources utilization: a potential source of income to support rural livelihoods. Applied Ecology and Environmental Sciences, v. 3, n. 6, p. 176-183, 2015.

ROSA, R. A. et al. Efeitos do tratamento preservativo e adesivo nas características mecânicas do laminado colado de duas espécies de bambu. Scientia Forestalis, v. 42, n. 103, p. 451-462, 2014. 
ROSA, R. A. et al. Influências da espécie, tratamento preservativo e adesivos nas propriedades físicas do bambu laminado colado. Ciência Florestal, v. 26, n. 3, p. 913-924, 2016.

TRADING ECONOMICS. China exports of bamboo products. 2018. Available at: $<$ https://tradingeconomics. com/china/exports-of-bamboo-products $>$. Access on: 15 Jan. 2019.
TRIANOSKI, R. et al. Avaliação das propriedades de painéis compensados de Melia azedarach L. produzidos com diferentes gramaturas e tempos de prensagem. Revista Árvore, v. 39, n. 4, p. 759-768, 2015.

VERMA, C. S. et al. Comparative study of mechanical properties of bamboo laminae and their laminates with woods and wood based composites. Composites: Part B, v. 60 , n. 1, p. $523-530,2014$. 